\title{
The Concept of Identity in the East Midlands of England
}

\author{
NATALIE BRABER
}

Investigating feelings of identity in East Midlands adolescents

\section{Introduction}

When considering dialectal variation in the UK, linguists have frequently considered the North/South divide and the linguistic markers separating the two regions (see for example Trudgill, 1999; Wells, 1986). But it has been noted that this is not a straightforward division (e.g. Beal, 2008; Goodey, Gold, Duffett \& Spencer, 1971; Montgomery, 2007; Wales, 2002). There are clear stereotypes for the North and South - but how do areas like the East Midlands fit into the picture? The boundaries between North and South are defined in different ways. Beal's linguistic North does not include the East Midlands (Beal, 2008: 1245), neither does Wales' (2002: 48). Trudgill states that in traditional dialectology the East Midlands area falls under 'Central' dialects, which come under the 'Southern' branch, but in modern dialectology it falls in the 'North'. Hughes, Trudgill and Watt (2005: 70) contains a map which has the East Midlands in the North. Linguistically, the question has been raised whether there is a clear North/South boundary (see for example Upton (2012) where it is proposed that it is a transition zone). This paper revisits this question from the point of view of young people living in the East Midlands, to examine their sense of identity and whether this cultural divide is salient to them.

The East Midlands is a problematic area in its definition geographically, and people may have difficulty in relating this to their own sense of identity. It seems that for many the North/South divide is a natural one (see for example Figure 1, where the man from the North shouts 'Oi, this fence should be further down!'), but what do non-linguists, and specifically young people, think?

Wales (2000) comments that although the East Midlands may be the geographical centre of England, it is not in any sense the perceived centre of England. It is an area which can be hard to locate perceptually and is referred to by Wales (2000: 7-8) as 'neither here nor there', and by Montgomery (2007: 352) as a 'no-man's land'. It seems that a definition of where the East Midlands is and what to call it is problematic, and in due course this paper will deal with these issues to attempt to resolve them. 


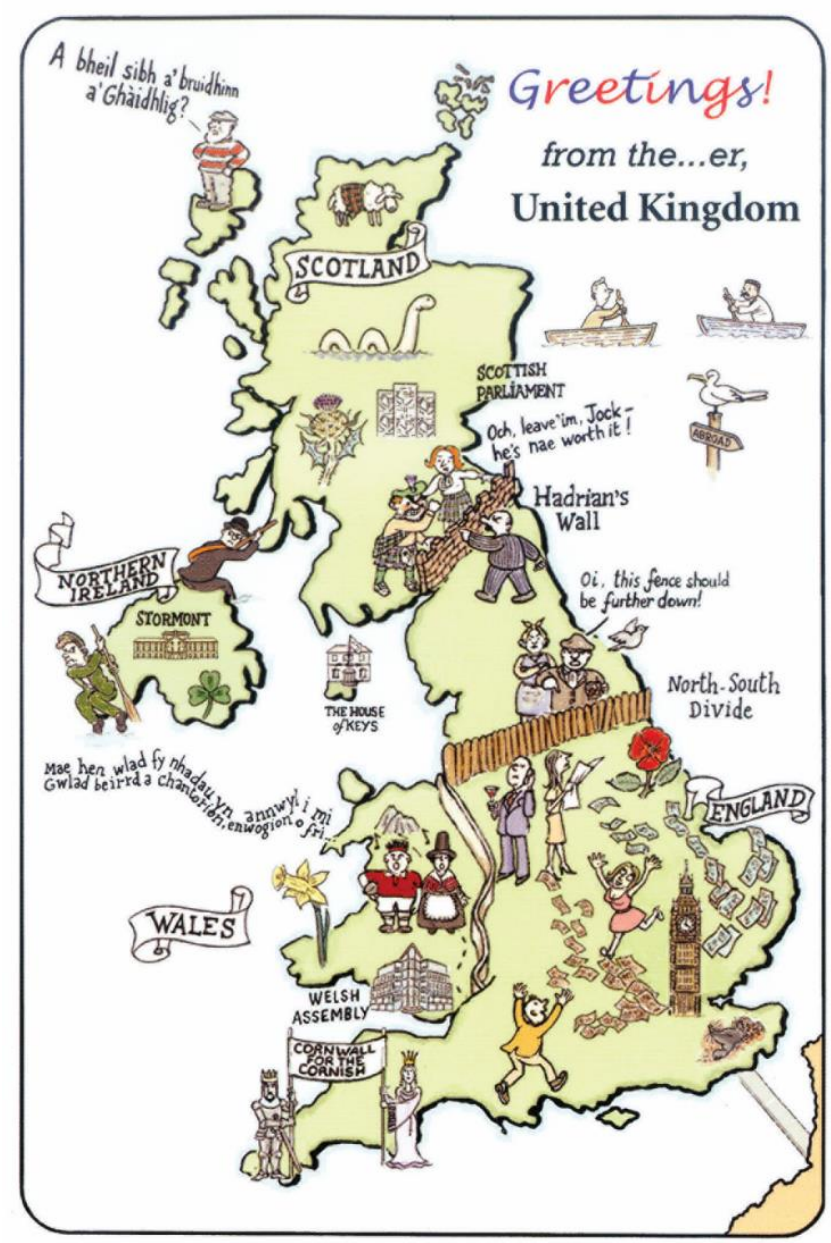

Figure 1: Where is the North/South divide? (This illustration comes from a postcard sold by the Nottingham Tourist Office entitled 'How to be British No.2' by Martyn Ford, www.lgpcards.com.)

\section{The Geography of the East Midlands}

The use of the term 'East Midlands' itself creates problems, with different terminology used to describe the area. We see the region being described in the literature as south Midlands (Britain, 2007); North-west, East, South and West Midlands (Hughes et al., 2005); Central Midlands (Trudgill, 1999) which is divided into West-Central and East-Central, and many indexes only include the term Midlands. Often terms are used without further clarification, so it is not always clear what is included in these descriptions. One edited collection (Britain, 2007) contains the terms West Midlands, Central Midlands, South Midlands, the Midlands, north west Midlands in different chapters, whereas other studies also use county names (for example Leicestershire, northern Nottinghamshire and north east Derbyshire in Trudgill, 1999: 42).

The Nomenclature of Territorial Units for Statistics (NUTS) 1 defines the East Midlands ${ }^{1}$ as containing the six counties shaded on Figure 2 . However, there are problems with such definitions, as they are not universally agreed upon in the literature, with particular problems surrounding Lincolnshire and Northamptonshire (see for example 
Beckett, 1988: 2-3). According to NUTS, the East Midlands forms England's fourth largest region, spread over $15.500 \mathrm{~km}^{2}$ and consists of most of the eastern half of the traditional region of the Midlands. It has a population of just under 5 million people, making it one of the less populated regions of the UK². The region includes a variety of types of town and countryside, ranging from the uplands of north-west Derbyshire to the lower levels of the Lincolnshire fens in the east. Industrial growth and rise of trade (due to the establishment of new road, water and rail communications) increased the importance of East Midlands towns, and by 1900 a new population structure emerged, with Nottingham, Leicester and Derby (along with their satellites) as greatly expanded urban centres. Migration from the surrounding countryside led to further population growth in these towns. However, there was never a distinctive regional capital, because both Nottingham and Leicester dominated their individual counties (Beckett, 1988: 5).

For this study, the 'three shires' as they are sometimes referred to by local residents and businesses (referring to Nottinghamshire, Derbyshire and Leicestershire) are examined, as they are frequently treated as the base of the East Midlands, both in official contexts and by many inhabitants. For example, the BBC East Midlands Today news programme, despite its title, currently excludes most of Northamptonshire, north Nottinghamshire and north Derbyshire, while most of Lincolnshire is covered by the BBC's Yorkshire and Lincolnshire region. Northamptonshire is part of the $B B C$ East region, based in Norwich, and can also receive Central News East, with the south of the county receiving Thames Valley. Given the important role of local news media in representing and constructing regional identity, this suggests that the counties of Lincolnshire and Northamptonshire might be regarded as peripheral to the 'core' East Midlands region, with the locations used for this study seen to represent the East Midlands. 


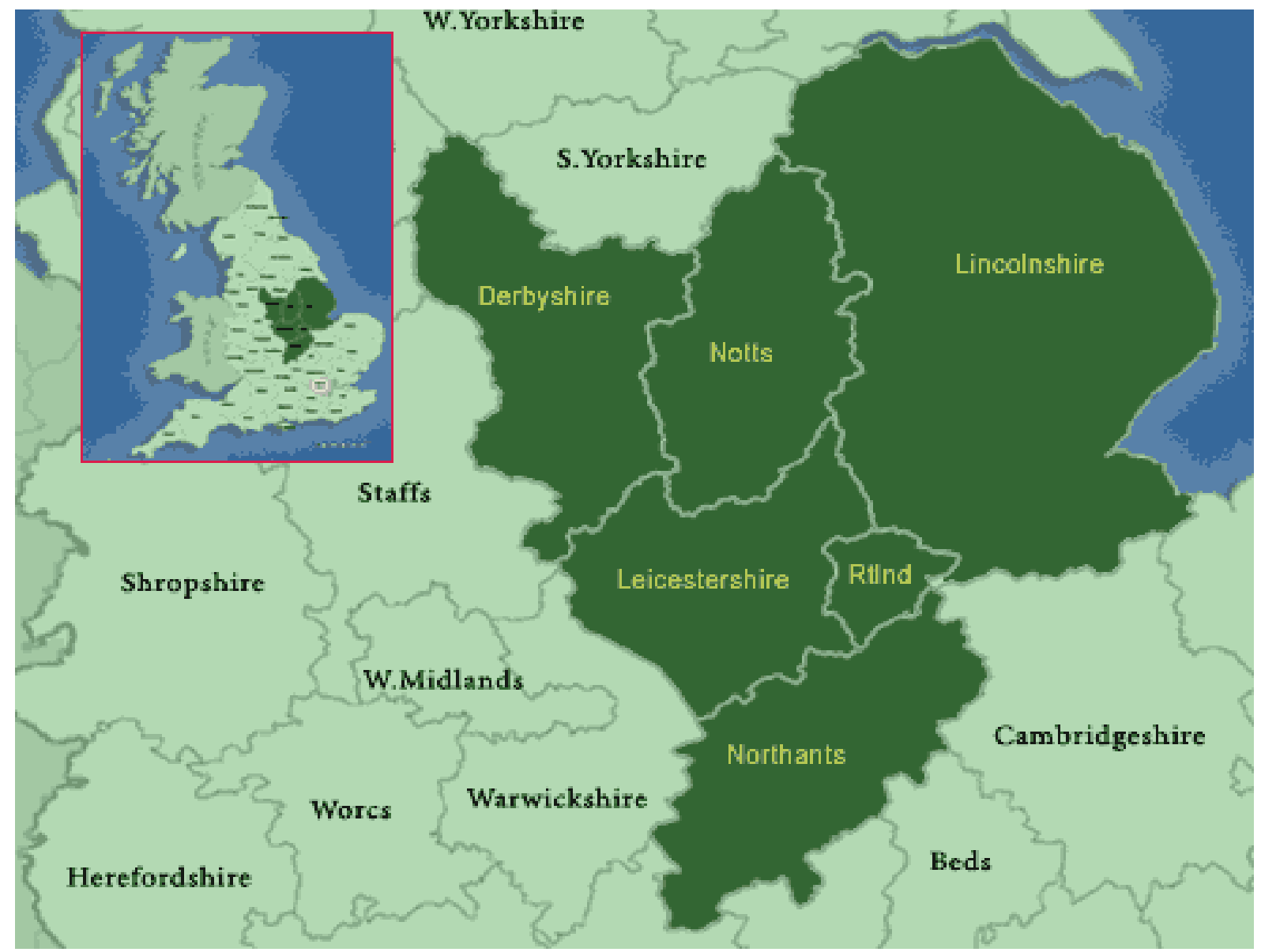

Figure 2: The East Midlands (map from www.picturesofengland.com)

\section{Language in the East Midlands}

Linguistic varieties of the East Midlands are interesting, because the dialect is said to belong to the northern dialect area as it shares similar features with those of the North (Beal, 2008: 124; Wells, 1986: 350) but there are also shared features with varieties found in southern England (Hughes et al., 2005: 63).

There has been no regional survey of the dialects of the East Midlands since the Survey of English Dialects in the 1950s (Orton et al., 1962-71). Much of the research on language in the East Midlands comes from a historical angle, where the dialect has been studied in relation to the development of Standard English (e.g. Baugh and Cable, 2002; Fennell, 2001). However, its characteristics as a living and changing dialect in the recent past and at the present time have received little attention. It is striking that existing publications that aggregate the findings of earlier surveys and more recent localised studies presenting an overview of regional speech in the UK are either lacking up-to-date research data from the East Midlands or simply ignore the region (e.g. Britain, 2007; Kortmann \& Upton, 2008). There are a few publications which focus on individual areas within the East Midlands, for example Foulkes and Docherty (1999) and Milroy (1996) who focus on Derby, and Flynn (2007) who examines Nottingham, as well as some which examine a specific linguistic feature over a wider area, such as Maidment (1995) and Upton (1995, 2012). 
There are also some non-academic pieces which examine language in the area, such as Scollins and Titford (2000), Wright (1986a and 1986b), Stennett and Scollins (2006) and Beeton (1999). Anecdotally it appears that language in the East Midlands remains distinctive (both within the region and compared to other regions) and local residents insist there is considerable difference, for instance, between speech in the major urban centres of Nottingham, Derby and Leicester (see for example Scollins and Titford, 2000: 5).

\section{Methodology}

The main goal of this study was to investigate where a group of East Midlands adolescents believe the linguistic North/South boundary to fall in the UK, and how they position themselves within this divide, i.e. do they think of themselves as 'Northerners', or 'Southerners' or as something else. The nature of the data collected meant that a great deal of preliminary processing was required which will be described in the next section. This study combines methods from studies by scholars such as Long, Fought, Diercks, Lance, and Coupland et al. (for full details see Preston, 1999).

I invited state secondary schools from across the East Midlands to take part in a study looking at language variation in the UK. For the study on which this paper is based, only Derbyshire, Leicestershire and Nottinghamshire were included. These counties include the three main urban centres of the region, containing the three largest cities, that is, Nottingham, Derby and Leicester, and as such as the most easily recognised centres of the East Midlands. Discussion of the further tasks undertaken by these students can be found in Braber (in preparation).

I asked permission to attend an hour-long class with students in their final year of school. These students were undertaking their final exams, A-Levels, and were around 1718 years old. The aim was to engage with students' opinions on language variation in the UK. Schools were not told in advance about considering the North/South divide or feelings of identification, to avoid prior discussion and students influencing one another. When contacting schools in the region, I ensured that both rural and urban schools were approached. Two schools in Leicestershire, three in Derbyshire and five in Nottinghamshire agreed to participate. Some of the schools specifically asked for A-Level English classes to be involved, whereas other schools were happy for all A-Level students to take part. This meant that some schools only had small groups of students participating, while others had larger groups. In all, 327 students were involved in this study (of which 191 in Nottinghamshire, 85 in Derbyshire and 51 in Leicestershire). The locations of the schools can be seen in Figure 3 below.

Participants were given a map of the UK and were informed that we would be carrying out a number of tasks to do with language variation and attitudes towards accents, as well as listening to some accents. Students were told there were no right or wrong answers and they should try to answer reflecting their own ideas and feelings as it was their opinions that we were interested in. Students were encouraged to carry out this work alone, without consulting others in the class as others' opinions may be different to their own. While carrying out these tasks, an overhead projector showed a map of the UK with some 
key cities marked (including Nottingham) as students are not always geographically aware of their own location.

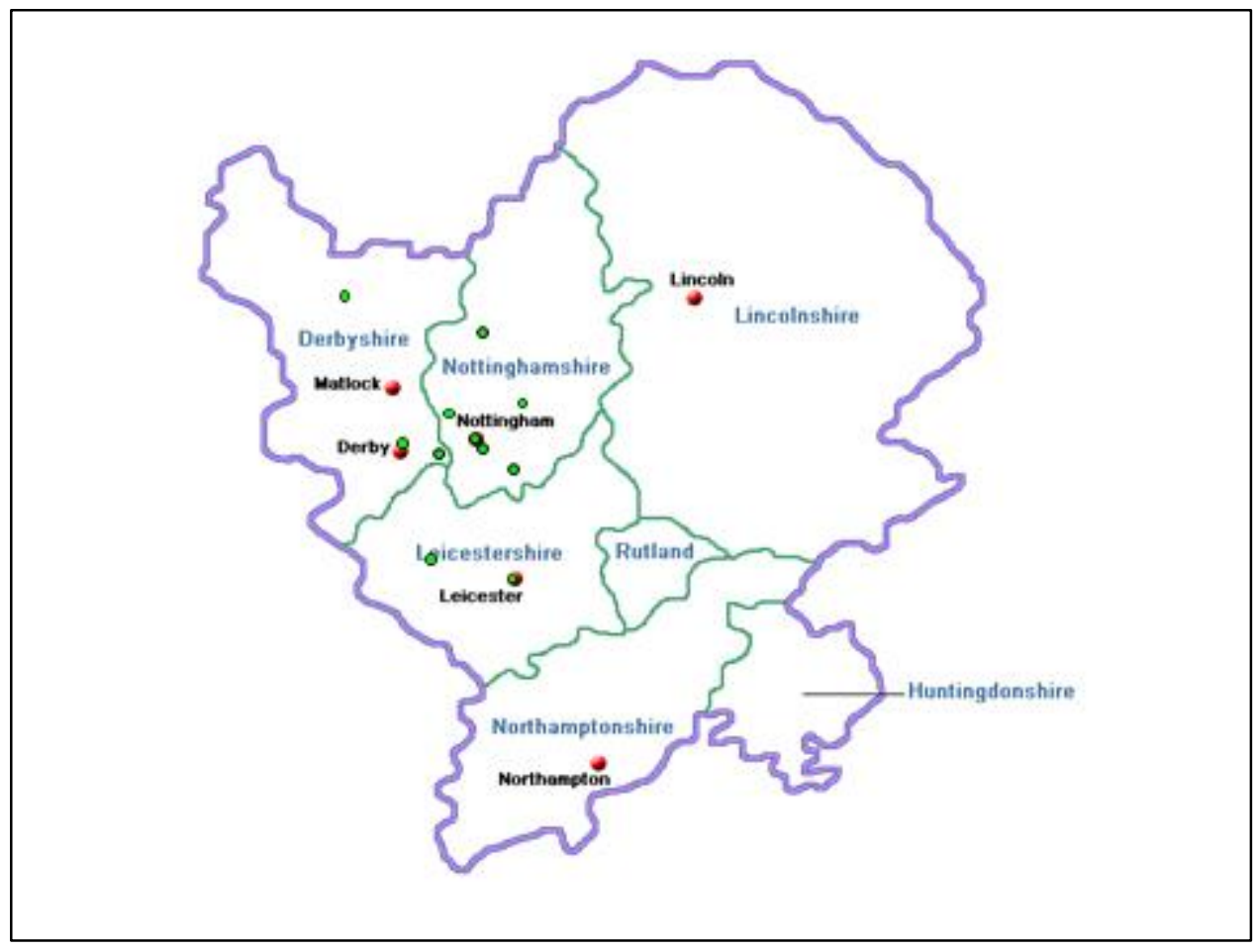

Figure 3: Locations of the school participating in the study (marked by the green circles)

The participants were asked to draw the North/South boundary (if they thought it existed) on the map given and then write next to the map whether they felt themselves to be Northern/Southern/Neither.

All 327 maps were projected onto one map (Figure 4) using Print Shop Pro 7, so that all student responses are visible from one map. This involved every map being scanned into this programme and allowed for the lines that the students drew to be processed in such a way that all maps could be layered on top of one another.

\section{Findings}

North/South Divide

In Figure 4 we see all 327 maps conflated in one map. This amalgamated figure illustrates the large range of different opinions held by all the students where the North/South divide is found. 


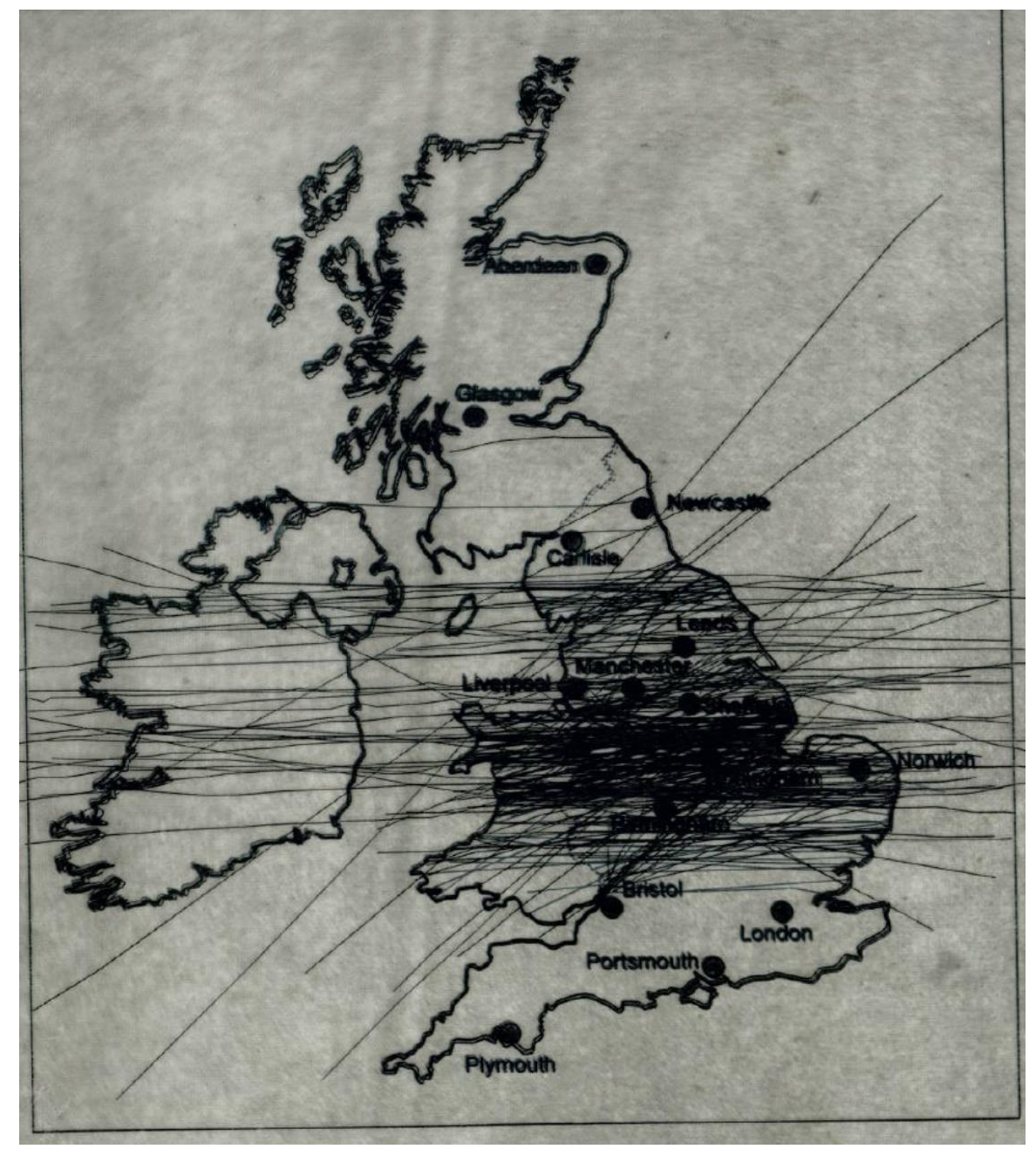

Figure 4: Where is the North/South divide?

The lines on Figure 4 range from just below Glasgow to just above London. The darkest area, where most lines were drawn, is found in the area in which the East Midlands is located. Most of the students drew a single line on this map (only 1\% left the map blank, showing that most students believed there is a North/South divide in the UK). 5\% drew two lines to indicate that they felt there should be a Midlands area in between the North and the South (and often wrote a note next to the map that they felt that it was not a case of North vs. South, but that a separate Midlands area existed). Interestingly, 12 out of total 19 participants who drew this tri-partite division were from Derbyshire schools and this can be compared to these students claiming a Midlander identity in the following task.

The main role of this map is to show the diversity of opinion on the concept of the North/South divide. For many this divide passes straight through the East Midlands. Furthermore, it indicates how salient this divide is, which clearly contrasts with the next task, asking about their own sense of identity, which many informants did not complete. The maps of individual respondents give other interesting insights, as there are some participants whose label of themselves (discussed in the following section) does not match up with their drawing of the North/South divide. For example, there are some people from Nottingham who called themselves Northerners but their line on the map does not match 
this as it places Nottingham below the divide, which would suggest they thought of Nottingham as belonging to the South. These maps also indicate how few drew the tripartite division although more did go on to label themselves as a 'Midlander' in the following task. As with Dorling's North/South divide (Dorling, 2007), it seems for many that this divide passed right through the East Midlands. Only one participant drew an East/West divide, which is interesting, as many of the participants later talked about the differences between East and West Midlands and how they felt very little connection with the West Midlands.

The map suggests that these students assumed that there is a divide when questioned, but also a disagreement about where it is situated. Only a small number distinguished a separate Midlands area (which is different in the next question). This may be the nature of working with young adults, who may be less likely to take their own initiative in some situations where adults disagree or feel uncertain. Further work has involved asking adults to make the same decisions and this is work currently in progress (Braber and Davies, forthcoming).

This first task has shown that these East Midlands students agreed that there is a North/South divide but that there is no clear consensus about where this divide is found. The next task involved asking students about their own sense of identity in relation to the North/South divide.

Northerner/Southerner/Neither

Once the students had been asked to draw the North/South divide, they were asked whether they considered themselves to be Northern/Southern/Neither. The results are illustrated in Figure 5 (the overall figures are given and these are broken down into the three counties as there were differences between them). We can see that although the question asked whether students felt themselves to be Northern, Southern or Neither, the answers could be further sub-divided as some additionally wrote 'Midlander' or 'East Midlander' on the map.

\begin{tabular}{|l|l|l|l|l|}
\hline Label & $\begin{array}{l}\text { Overall } \\
(327)\end{array}$ & $\begin{array}{l}\text { Nottinghamshire } \\
(191)\end{array}$ & $\begin{array}{l}\text { Derbyshire } \\
(85)\end{array}$ & $\begin{array}{l}\text { Leicestershire } \\
(51)\end{array}$ \\
\hline Northern & $50(15 \%)$ & $40(21 \%)$ & $6(7 \%)$ & $4(8 \%)$ \\
\hline Southern & $44(13 \%)$ & $27(14 \%)$ & $6(7 \%)$ & $11(22 \%)$ \\
\hline Midlander & $47(14 \%)$ & $26(14 \%)$ & $12(14 \%)$ & $9(18 \%)$ \\
\hline Neither & $83(26 \%)$ & $42(22 \%)$ & $27(32 \%)$ & $14(27 \%)$ \\
\hline Blank & $99(31 \%)$ & $52(27 \%)$ & $34(40 \%)$ & $13(25 \%)$ \\
\hline Other & $4(1 \%)$ & $4(2 \%)$ & 0 & 0 \\
\hline
\end{tabular}

Figure 5: Northern vs. Southern? 
It seems that although most students agreed on the concept of a North/South divide in the UK as was shown in the previous task, many did not have an expressed affiliation with the North or the South. This question was left blank by almost a third of all participants. The category 'Neither' was the second most popular choice. These students specified by answering 'Neither' that they did not feel that they belong to 'Northern' or 'Southern', whereas the students leaving this question blank may be showing that although they feel they are aware of the divide, they are not sure about how this division applies to them and their own identity. The option of 'Midlander' or 'East Midlander' was not given in the question as it was believed this may lead the students to answer this and this study was interested to see whether students would name this spontaneously. Looking at the overall figures, the totals for 'Northern', 'Southern' and 'Midlander' appear to be very similar to one another.

If we break this down into the individual counties we can see some differences between the groups ${ }^{3}$. Of the Nottinghamshire participants (of which there were 191) almost half answered either 'Neither' or left this question blank. Forty participants (21\%) labelled themselves as 'Northern' and a smaller proportion ( $14 \%$ for both) thought of themselves as 'Southern' or 'Midlander' (only 1\% chose to define themselves as something else, for example English or British, which no other students used). So while $50 \%$ of the Nottinghamshire students did not feel themselves to belong to any particular category a relatively high number felt 'Northern'. Derbyshire showed a slightly different pattern. An overwhelming $72 \%$ felt themselves not to belong to any category or left the question blank. Compared to the Nottinghamshire students fewer Derbyshire students selected 'Northern' (7\%) or 'Southern' (7\%) and a larger proportion gave themselves the label 'Midlander' (14\%). Leicestershire was different again. Although again a larger proportion (52\%) either left this question blank or gave the answer 'Neither', and a similar proportion labelled themselves 'Midlander' (18\%) as compared to the other two counties, this group had the largest proportion of participants labelling themselves as 'Southern' (22\%).

Overall, it seems that large numbers of students in the three counties seemed to be unsure about their identity as they left this question blank, although a large group believed themselves not to belong to these groups. It seems that most of the students were aware of the North/South divide, but many did not feel they belong to either side of that divide. It is therefore interesting to see that the actual divide itself was a salient one for these participants, but that they are less sure of their own categorisation.

Leaving aside the blank or 'Neither' categorisations, in Nottinghamshire many felt themselves to be 'Northerner', while in Derbyshire a high number identified themselves as 'Midlander'. In Leicestershire many students believed themselves to be 'Southerner'. Of these three counties, Leicestershire is geographically the most southern, which could have influenced these students in selecting this identity.

\section{Discussion}

This study shows that samples of sixth-year secondary school pupils in the East Midlands counties of Nottinghamshire, Derbyshire and Leicestershire generally felt that there is a North/South divide in the UK, and were happy to draw a line illustrating it. However, these 
two tasks have shown that the East Midlands area may be problematic in terms of where it belongs or how people identify themselves. The area where this divide is identified varies greatly between informants, from the very north of England to very south. As the participants in this study live very close to where researchers have suggested the North/South divide may fall (see Dorling, 2007), these results contradict the findings of Montgomery $(2007: 64,127)$ that people living closest to the North/South divide are more likely to agree about where the boundary lies as they have a vested interest in 'knowing' where it is. However, the 'Midland' group in Montgomery's study were from Crewe which is in the very western-most part of the West Midlands and there may be a distinction between these two areas.

Although almost all students were happy to state that there is a North/South divide (regardless of where it is placed), most students are less sure which group they belong to or say they do not feel as if they belong to the North or the South. Geographical location could play a role in this for some students, because students from the most southern county in these samples, Leicestershire, were more likely to label themselves as 'Southern' (than 'Northern' or 'Midlander'), while those from Nottinghamshire were most likely to label themselves as 'Northern' and those from Derbyshire as 'Midlander'. What is also interesting is that students did not comment on an East/West divide (see also Upton, 2012: 267) although there is a West Midlands that they could differentiate themselves from. A further issue which could be raised in the cases where the students answered 'Neither' is whether they felt themselves to belong to the East Midlands or Midlands even though they have not specifically written this as some of the other students had done.

Future work could also include examining the zones where the majority of participants draw this line (as in Montgomery, 2007) to further break down where this divide is believed to be by the majority of participants. Such work might include a qualitative element employing detailed questionnaires and focus groups with participants.

Wales comments that there are North/South stereotypes which may be "irritating" (Wales, 2000: 15) but having an identity in opposition to another identity (i.e. being Northern as opposed to Southern, or Scottish as opposed to English) is important to many people - so what is happening to these participants? It is interesting that a relatively large proportion gave the term 'Midlander' even though this was not an option, as it shows that there is a sense of there being a separate identity rather than belonging to the North or South.

\section{Conclusion}

It seems clear that there is uncertainty about the position of the East Midlands and where it belongs in the country. The fact that a relatively high number of participants chose 'Midlander' is interesting as it suggests an idea of a separate (i.e. non-'North/South') identity. But there are limitations in understanding from the present data exactly what the students who said 'Neither' mean in their responses, and whether some may have felt unable to suggest 'Midlander' as it was not an option explicitly stated to them.

Intended future work will therefore include obtaining students' responses to questions about language variation in the UK and how the East Midlands fits into this. Do they think there are 'typical' features of East Midlands language? This work will also include 
examining the ability of these students to recognise various accents from around the UK and to see how accurate they are at local varieties (see Braber, in preparation).

Further research which is suggested by this present enquiry would be to carry out work with adults to discover whether similar patterns are found on placing the North/South divide, how they would categorise themselves and how accurately they can identify local voices. This study did not explicitly consider travel experience or media influence but these could also be interesting issues for future work.

\section{Notes}

I See: http://www.ons.gov.uk/ons/guide-method/geography/beginner-sguide/eurostat/east-midlands--england-/index.html for full information.

2 According to the Office of National Statistics, for more information see http://www.statistics.gov.uk/hub/population/population-change/populationestimates/index.html.

${ }^{3}$ Although we can see in Figure 3 that certain schools within a country may be further to the north or south than other schools, there are similarities between the counties which are more salient than differences between schools in these counties.

\section{References}

Baugh, A. C. \& Cable, T. 2002. A history of the English language. $5^{\text {th }}$ edition. London: Routledge.

Bayard, D. 1990. "God help us if we all sound like this': attitudes to New Zealand and other English accents'. In A. Bell \& J. Holmes (eds.), New Zealand ways of speaking English. Clevedon: Multilingual Matters, pp. 67-96.

Beal, J. 2008. 'English dialects in the North of England: phonology'. In B. Kortmann \& C. Upton (eds.), Varieties of English 1: The British Is/es. Berlin: Mouton de Gruyter, pp. $122-144$.

Beckett, J.V. 1988. The East Midlands from AD 1000. London: Longman. Beeton, J. 1999. Nottingham as it is Spoke. Nottingham: JB Enterprises.

Braber, N. and Davies, D. Forthcoming. 'Charting Language Change and Identity in the East Midlands'. Multilingua.

Braber, N. In preparation. 'Language perception in the East Midlands of England'.

Britain, D. (ed.) 2007. Language in the British Is/es. Cambridge: Cambridge University Press. Coupland, N., Williams, A. \& Garrett, P. 1999. 'Welshness' and 'Englishness' as Attitudinal Dimensions of English Language Varieties in Wales'. In D. Preston (ed.), The Handbook of Perceptual Dialectology, volume 1. Philadelphia: Benjamins, pp. 333343.

Diercks, W. 2002. 'Mental Maps'. In D. Long \& D. Preston (eds.), The Handbook of Perceptual Dialectology, volume 2. Philadelphia: Benjamins, pp. 51-70. 
Dorling, D. 2007. 'The North-South Divide. Where is the line?' Online at $<$ http:// sasi.group.shef.ac.uk/maps/nsdivide/index.html> (Accessed January 28, 2012).

Fennell, B. 2001. A history of English. A sociolinguistic approach. Oxford: Blackwell.

Flynn, N. 2007. 'A sociophonetic comparison of adolescent speech in two areas of Nottingham.' Unpublished MA thesis. Essex: University of Essex.

Foulkes, P. \& Docherty, G. 1999. 'Derby and Newcastle: instrumental phonetics and variationist studies'. In P. Foulkes \& G. Docherty (eds.), Urban voices: Accent studies in the British Is/es. London: Arnold, pp. 47-71.

Fought, C. 2002. 'California Students' Perceptions of, You Know, Regions and Dialects?' In

D.

Long \& D. Preston (eds.), The Handbook of Perceptual Dialectology, volume 2. Philadelphia: Benjamins, pp. 113-134.

Fox, A. 2009. A Lost Frontier Revealed. Regional Separation in the East Midlands. Hertfordshire: University of Hertfordshire Press.

Goodey, B., Gold, J., Duffett, A. \& Spencer, D. 1971. City Scene. An exploration into the image of Central Birmingham as seen by area residents. University of Birmingham: Centre for Urban and Regional Studies.

Hughes, A., Trudgill, P. \& Watt, D. 2005. English accents and dialects. London: Hodder Arnold.

Kortmann, B. \& Upton, C. (eds.) 2008. Varieties of English 1: The British Is/es. Berlin: Mouton de Gruyter.

Lance, D.M. 1999. 'Regional Variation in Subjective Dialect Divisions in the United States'. In D. Preston (ed.), The Handbook of Perceptual Dialectology, volume 1. Philadelphia: Benjamins, pp. 283-314.

Long, D. 1999a. 'Geographical Perceptions of Japanese Dialect Regions'. In D. Preston (ed.), The Handbook of Perceptual Dialectology, volume 1. Philadelphia: Benjamins, pp. 177-198.

Long, D. 1999b. 'Mapping Nonlinguists' Evaluations of Japanese Language Variation'. In D. Preston (ed.), The Handbook of Perceptual Dialectology, volume 1. Philadelphia: Benjamins, pp. 199-226.

Long, D. \& Preston, D. (eds.) 2002. The Handbook of Perceptual Dialectology, volume 2. Philadelphia: Benjamins.

Maidment, J.A. 1995. 'A Neglected Feature of British East Midlands Accents and its Possible Implications for the History of a Vowel Merger in English'. In J. Windsor Lewis (ed.), Studies in General and English Phonetics. London: Routledge, pp. 379-384.

Milroy, J. 1996. 'A Current Change in British English: Variation in (th) in Derby'. Newcastle and Durham Working Papers in Linguistics, 4, 213-222.

Montgomery, C. 2007. 'Northern English Dialects: A Perceptual Approach'. Unpublished PhD Thesis. Sheffield: The University of Sheffield.

Orton, H., Dieth, E., Halliday, W., Barry, M., Tilling, P. \& Wakelin, M. 1962-1971. Survey of English Dialects $A$ and B: Introduction and The Basic Material. Introduction and 4 volumes, each of 3 parts. Leeds: E.J. Arnold \& Son.

Preston, D. (ed.) 1999. The Handbook of Perceptual Dialectology, volume 1. Philadelphia: Benjamins. 
Read, C. 1981. The East Midlands. Hyde: Westgate Educational Publishing Company.

Scollins, R. \& Titford, J. 2000. Ey up mi duck! Dialect of Derbyshire and the East Midlands. Newbury: Countryside Books.

Stennett, A. \& Scollins, R. 2006. Nobbut a Yellerbelly! Newbury: Countryside Books.

Trudgill, P. 1999. The dialects of England. $2^{\text {nd }}$ edition. Oxford: Blackwell.

Upton, C. 1995. 'Mixing and Fudging in Midland and Southern Dialects of England: The cup and foot vowels'. In J. Windsor Lewis (ed.), Studies in General and English Phonetics. London: Routledge, pp. 385-394.

Upton, C. 2012. 'The Importance of Being Janus'. In M. Markus, Y. Iyeiri, R. Henberger \& E. Chamson (eds.), Middle and Modern English Corpus Linguistics. Amsterdam: John Benjamins, pp. 257-268.

Virgo, H.E. 1975. The East Midlands. London: The English Universities Press.

Wales, K. 2000. 'North and South: An English linguistic divide?' English Today, 16(1), 4-15.

Wales, K. 2002. "North of the Watford Gap'. A cultural history of Northern English (from 1700)'. In R. Watts and P. Trudgill (eds.), Alternative histories of English. London: Routledge, pp. 45-66.

Wells, J.C. 1986. Accents of English 2: The British Is/es. Cambridge: Cambridge University Press.

Wright, P. 1986a. Derbyshire Drawl: How it is Spoke. Skipton: Dalesman Publishing.

Wright, P. 1986b. Notts Natter: How it is Spoke. Skipton: Dalesman Publishing. 